\title{
PENINGKATAN KEMAMPUAN MENYIMAK DONGENG DENGAN METODE MIND MAP MELALUI MEDIA ANIMASI AUDIO VISUAL DALAM MATA KULIAH MENYIMAK KARYA SASTRA DI IKIP BUDI UTOMO MALANG
}

\author{
Luly Zahrotul Lutfiyah \\ IKIP Budi Utomo Malang \\ E-mail : lulylutfiyah@gmail.com
}

\begin{abstract}
This research aims to (1) describe the implementation of mind map method through audiovisual animation media in improving listening to fairy tale ability, (2) describe the achievement level of mind map method through audiovisual animation media in defining interesting parts from the fairy tale including (figure, character, and theme), (3) describe achievement level of mind map method through audiovisual animation media in showing interesting parts about the relevance between theme and recent situation, (4) describe achievement level of mind map method through audiovisual animation media in defining interesting parts of a fairy tale using logical reason, (5) describe achievement level of mind map method through audiovisual animation media in improving the ability to conclude the message of a fairy tale. This is a classroom action research (CAR). The data collection applies five techniques such as (1) Observation, (2) Interview, (3) Test, (4) Documentation, dan (5) Field Note. Mind map teaching method through audiovisual animation media can improve ability in listening to fairy tale for the IKIP BUDI UTOMO Students. Based on evaluation result from cycle 1 and cycle 2, it is confirmed that the cumulative score improves; also, each aspect experiences the same improvement - except in the attractiveness of fairy tale relevance. Content comprehension aspect at cycle 1 gets score in percentage of $82 \%$ and at cycle 2 makes $90 \%$. Fairy tale attracting parts aspect at cycle 1 reaches score in percentage of $34 \%$ and becomes 51\% at cycle 2; fairy tale relevance attractiveness aspect at cycle 1 has score in percentage of $62 \%$, and $54 \%$ at cycle 2; the aspect of expressing fairy tale interesting parts in logical reason at cycle 1 makes percentage score as many as $74 \%$ and becomes $87 \%$ at cycle 2, fairy tale conclusion message aspect at cycle 1 makes score of $75 \%$, and $79 \%$ at cycle 2; furthermore, the student cumulative score in cycle 1 is $72 \%$ and becomes $80 \%$ at cycle 2. From the observation result, there also occurs improvement, and generally the teaching and learning atmosphere is quite conducive. The class situation is controllable, students feel favorable to mind map method and fairy tale VCD which are used as the media to listen to the fairy tale. Student interest in following fairy tale listening activity is relatively high. Things to suggest for further research, suppose it explores the implementation of mind map teaching method in the effort of improving student's affective aspect. For Bahasa Indonesia teacher, suppose he/she applies mind map teaching method through audiovisual animation media as a kind of variation in teaching method to make student not bored while joining the learning.
\end{abstract}

Keywords: listening ability, listening teaching, mind map method through audiovisual animation media, listening ability improvement

Menyimak digunakan dalam segala aktivitas kehidupan manusia. Dengan kata lain, manusia selalu dituntut untuk menyimak, baik di lingkungan keluarga, di sekolah, maupun di masyarakat. Di lingkungan keluarga, manusia selalu dituntut menyimak. Pemerolehan bahasa seseorang berawal dari kegiatan menyimak ujaran di lingkungan keluarganya. Peran penting penguasaan keterampilan menyimak juga sangat tampak di lingkungan sekolah. Siswa menggunakan sebagian besar waktunya untuk menyimak pelajaran yang disampaikan guru. Keberhasilan siswa memahami serta menguasai pelajaran diawali oleh kemampuan menyimak yang benar. Dengan demikian, keterampilan menyimak perlu dikuasai oleh mahasiswa secara efektif dan efisien. Meskipun demikian, dalam pelaksanaan pembelajaran di sekolah penguasaan terhadap ketrampilan menyimak pada umumnya masih diabaikan, termasuk menyimak dongeng. Penyebab pengabaian pembelajaran ketrampilan tersebut adalah mahasiswa menganggap pembelajaran menyimak dongeng merupakan pembelajaran yang mudah dilakukan sehingga mereka tidak antusias terhadap pembelajaran. Mahasiswa menganggap keterampilan menyimak dongeng merupakan keterampilan yang paling mudah 
dibandingkan dengan keterampilan berbahasa yang lain. Hal tersebut mengakibatkan keterampilan menyimak kurang dikuasai dengan baik. Padahal, penguasaan keterampilan berbahasa yang lain: membaca, berbicara dan menulis, penyampaiannya dengan proses menyimak.

Penelitian ini diharapkan bermanfaat untuk mengembangkan teori-teori, khususnya pembelajaran keterampilan menyimak karya sastra bahasa Indonesia sehingga dapat meningkatkan kualitas hasil pembelajaran dan mutu pendidikan pada umumnya. Dengan menggunakan metode mind map melalui media animasi audiovisual, pembelajaran diharapkan menjadi lebih variatif. Dengan demikian, hasil belajar mahasiswa, khususnya dalam pembelajaran keterampilan menyimak dongeng dapat ditingkatkan. Manfaat penelitian ini bagi dosen adalah (1) memperkaya khasanah metode dan metode pembelajaran, khususnya dalam pembelajaran keterampilan menyimak dongeng; (2) memperbaiki metode pembelajaran yang selama ini digunakan; dan (3) menciptakan kegiatan belajar mengajar yang menarik dan tidak membosankan. Manfaat bagi mahasiswa adalah: (1) membantu mahasiswa mengatasi kesulitan dalam pembelajaran keterampilan menyimak, khususnya pembelajaran keterampilan menyimak dongeng; (2) memotivasi mahasiswa untuk belajar lebih giat; dan (3) melatih serta membiasakan mahasiswa melakukan kegiatan menyimak secara efisien dan efektif.

Metode mind map adalah cara mencatat yang langkah-langkah pembuatannya menyesuaikan dengan cara kerja otak atau menggunakan cara-cara yang dapat merangsang otak seperti menggunakan berbagai macam warna, garis lengkung, gambar dan sebagainya sehingga tidak membuat otak cepat bosan sehingga dapat meningkatkan daya ingat dan meningkatkan konsentrasi.

\section{METODE}

Pendekatan yang digunakan dalam penelitian ini adalah penelitian kualitatif interaktif . Jenis penelitiannya adalah Penelitian Tindakan Kelas (PTK). Arikunto dkk (2006: 58) menjelaskan bahwa penelitian tindakan kelas adalah penelitian tindakan (Action Research) yang dilakukan dengan tujuan memperbaiki mutu praktek pembelajaran di kelas. Penelitian ini menggunakan prosedur tindakan kelas. Penelitian tindakan kelas dapat didefinisikan sebagai bentuk kajian yang bersifat reflektif oleh pelaku tindakan yang dilakukan untuk meningkatkan kemampuan rasional dari tindakan-tindakan mereka dalam melaksanakan tugas memperdalam pemahaman terhadap tindakan yang dilakukan, serta memperbaiki kondisi dimana praktik pembelajaran tersebut dilakukan.

Penelitian ini dilaksanakan pada mahasiswa kelas A angkatan 2014 IKIP Budi Utomo Malang. Peneliti memilih penelitian di IKIP Budi Utomo Malang karena peneliti mengajar di IKIP Budi Utomo Malang. Peneliti menemukan masalah aktivitas mahasiswa kurang begitu terlihat dalam pembelajaran, daya ingatnya kurang dan hasil belajarnya juga banyak yang di bawah SKM (Standar Ketuntasan Minimal). Seperti contohnya dalam pembelajaran menyimak karya sastra berupa dongeng. Pemahaman siswa dalam menyimak dongeng masih sangat rendah. Selain itu, di IKIP Budi Utomo Malang belum pernah dilakukan penelitian tentang penggunaan metode pembelajaran mind map.

\section{HASIL}

Berdasarkan hasil evaluasi siklus 1 dan siklus 2 dapat dibuktikan perolehan skor kumulatif terjadi peningkatan dan masingmasing aspek juga terjadi peningkatan kecuali pada aspek kemenarikan relevansi dongeng. Aspek pemahaman isi pada siklus 1 memperoleh persentase skor sebesar $82 \%$ dan siklus 2 sebesar 90\% sehingga terjadi peningkatan sebesar $8 \%$. Aspek kemenarikan unsur dongeng pada siklus 1 memperoleh persentase skor sebesar 34\% dan siklus 2 sebesar $51 \%$ sehingga terjadi peningkatan sebesar $17 \%$, aspek kemenarikan relevansi dongeng siklus 1 memperoleh persentase skor sebesar $62 \%$ dan siklus $254 \%$ sehingga terjadi penurunan sebesar $8 \%$, aspek mengungkapan hal-hal menarik dalam dongeng dengan alasan yang logis siklus 1 memperoleh persentase skor sebesar $74 \%$ dan siklus 2 sebesar $87 \%$ sehingga memperoleh kenaikan sebesar $13 \%$, aspek kesimpulan pesan dongeng siklus 1 memperoleh persentase skor sebesar $75 \%$ dan siklus 2 sebesar $79 \%$ sehingga memperoleh kenaikan sebesar $4 \%$, dan skor kumulatif siswa siklus 1 memperoleh 
persentase skor sebesar $72 \%$ dan siklus 2 sebesar $80 \%$ sehingga memperoleh kenaikan sebesar $8 \%$.

Dari hasil observasi juga terjadi peningkatan, secara umum kondisi pembelajaran cukup kondusif. Situasi kelas dapat dikendalikan, mahasiswa merasa senang dengan metode mind map dan VCD dongeng yang digunakan sebagai media untuk menyimak dongeng. Minat mahasiswa dalam mengikuti kegiatan menyimak dongeng cukup besar. Dari hasil penelitian ini dapat diperoleh temuan bahwa penerapan metode pembelajaran mind map melalui media animasi audiovisual dapat meningkatkan kemampuan mahasiswa dalam menyimak dongeng.

\section{PEMBAHASAN}

Penerapan Metode Mind Map melalui Media Animasi Audiovisual dalam Meningkatkan Kemampuan Menyimak Dongeng pada Mata Kuliah Menyimak Karya Sastra di IKIP Budi Utomo Malang

Berdasarkan hasil tes pratindakan menunjukkan bahwa tingkat kemampuan menyimak karya sastra mahasiswa masih rendah. Mahasiswa kesulitan menentukan hal menarik dari unsur dongeng yang meliputi tokoh, tema, watak, dan latar dongeng yang diperdengarkan, menunjukkan hal menarik tentang relevansi dongeng dengan situasi sekarang, mengemukakan hal menarik dalam dongeng yang diperdengarkan, dan menyimpulkan pesan dari dongeng yang diperdengarkan. Pembelajaran yang dilakukan dosen dengan cara memberikan bacaan kepada mahasiswa untuk dibaca mahasiswa sendiri bukan dibacakan oleh dosen. Selain itu belum ada media yang digunakan dosen. Oleh karena itu perlu adanya solusi melalui peningkatan inovasi metode pembelajaran. Dengan adanya penerapan metode baru, yaitu metode mind map melalui media animasi audio visual mampu meningkatkan kemampuan menyimak mahasiswa.

Dengan metode pembelajaran mind map melalui media animasi audiovisual, membuat mahasiswa IKIP Budi Utomo merasa senang dan semangatnya meningkat serta dapat menghilangkan kebosanan dalam mengikuti pembelajaran. Langkah-langkah dalam pembuatan mind map ini disesuaikan d engan cara kerja otak. Pertama, memulai dari bagian tengah memberi kebebasan kepada otak untuk menyebar ke segala arah dan memberikan kebebasan kepada siswa untuk berkreasi. Kedua, menggunakan gambar, karena gambar membuat lebih menarik, membuat siswa tetap fokus, membantu berkonsentrasi dan mengaktifkan otak. Ketiga, warna, karena bagi otak, warna sama menariknya dengan gambar, menambah energi kepada pemikiran kreatif, dan menyenangkan. Keempat, membuat garis hubung yang melengkung, bukan garis lurus, karena garis lurus akan membosankan otak (Buzan 2010:15). Setelah langkah-langkah tersebut selesai, mahasiswa melaporkan hasilnya di depan kelas dan mahasiswa yang lain bisa memberikan tanggapan, saran, masukan, apabila masih terdapat kekurangan. Dengan demikian, penelitian ini menerapkan metode pembelajaran mind map melalui media animasi audiovisual untuk pembelajaran menyimak dongeng di kelas A, yang dilakukan sebanyak 2 siklus, setiap siklus terdiri dari 2 pertemuan. Penelitian ini membuktikan bahwa dalam pelaksanaan pembelajaran sangat diperlukan ketepatan dalam pemilihan materi dan metode yang sesuai serta perencanaan pelaksanaan pembelajaran dapat mempengaruhi proses belajar mengajar. Dengan adanya pemilihan yang tepat, akan membuat pembelajaran bermakna bagi siswa.

Penerapan Metode Pembelajaran Mind Map melalui Media Animasi Audio Visual dalam Meningkatkan Kemampuan Menentukan Hal Menarik dari Unsur Dongeng yang Meliputi Tokoh, Watak, Tema, Latar Dongeng

Berdasarkan hasil temuan lengkap diketahui bahwa peningkatan yang terjadi pada aspek menentukan hal menarik dari unsur dongeng yang meliputi tokoh, watak, tema dan latar pada siklus 1 memperoleh persentase skor sebesar $34 \%$ dan siklus 2 sebesar $51 \%$ sehingga terjadi peningkatan sebesar $17 \%$.

Peningkatan pada setiap aspek dalam pembelajaran menyimak dongeng disebabkan oleh adanya perbaikan-perbaikan yang dilakukan pada setiap pembelajaran. Pada aspek unsur, peningkatan kemampuan menyimak dongeng didorong oleh adanya pengetahuan awal dari mahasiswa. Sebelum kompetensi dasar menyimak dongeng, mahasiswa telah mendapat pembelajaran dongeng dalam pembelajaran membaca sehingga mahasiswa dimotivasi kembali untuk mengingat hal-hal yang berkaitan dengan unsur dongeng yang meliputi tokoh, 
watak, tema dan latar. Peran metode mind map melalui media animasi audio visual juga sangat besar karena dengan VCD dongeng yang disimak dan mind map yang dibuat mahasiswa akan memudahkan mahasiswa untuk menjawab soal evaluasi yang berkaitan dengan unsur dongeng yang meliputi tokoh, watak, tema dan latar.

Penerapan Metode Pembelajaran Mind Map melalui Media Animasi Audio Visual dalam Meningkatkan Kemampuan Menunjukkan Hal Menarik tentang Relevansi Tema dengan Situasi Sekarang

Berdasarkan hasil temuan lengkap diketahui bahwa telah terjadi penurunan persentase skor pada aspek menentukan kemenarikan relevansi tema dengan situasi sekarang. Aspek kemenarikan relevansi dongeng siklus 1 memperoleh persentase skor sebesar $62 \%$ dan siklus $2,54 \%$ sehingga terjadi penurunan sebesar $8 \%$. Hal ini disebabkan o leh pengetahuan siswa terhadap relevansi tema dalam dongeng kurang bisa mengaplikasikannya dengan situasi sekarang. Sebagian mahasiswa merasa bingung menunjukkan kemenarikan relevansi tema dengan kehidupan sekarang, misalnya saja menentukan hal-hal ajaib/ aneh dalam dongeng terjadi dalam kehidupan saat ini, sebagian mahasiswa mengalami kesulitan menunjukkan relevansi keajaiban/keanehan itu terjadi dalam kehidupan sehari-hari, sebagian mahasiswa mengalami kesulitan menunjukkan relevansi nilai-nilai yang ada dalam dongeng tersebut masih sesuai atau tidak jika diterapkan dalam kehidupan sekarang.

Penerapan Metode Pembelajaran Mind Map melalui Media Animasi Audio Visual dalam Meningkatkan Kemampuan Mengungkapan Hal-hal Menarik Dalam Dongeng yang Disimak dengan Alasan yang Logis

Berdasarkan hasil temuan lengkap diketahui bahwa peningkatan yang terjadi pada aspek mengungkapan hal-hal menarik dalam dongeng dengan alasan yang logis pada siklus 1 memperoleh persentase skor sebesar $74 \%$ dan siklus 2 sebesar $87 \%$ sehingga memperoleh kenaikan sebesar $13 \%$.

Pada aspek mengungkapan hal-hal menarik dalam dongeng dengan alasan yang logis siswa tidak terlalu mengalami kesulitan.
Namun, mahasiswa perlu pemahaman dalam memberi alasan yang sesuai dengan hal menarik yang diungkapkannya. Untuk itu dosen berusaha untuk memberi contoh dengan tetap melibatkan mahasiswa. Sebagai contoh guru memberikan dua jenis judul dongeng yaitu Bawang Merah dan Bawang Putih dan dongeng Timun Emas yang dikemas dalam bentuk media animasi audiovisual dan dicatat menggunakan metode mind map untuk memudahkan mahasiswa menjawab soal evaluasi khususnya tentang aspek mengungkapkan hal-hal menarik dalam dongeng yang disimak dengan alas an yang logis.

Penerapan Metode Pembelajaran Mind Map melalui Media Animasi Audio Visual dalam Meningkatkan Kemampuan Menyimpulkan Pesan Dongeng

Pada aspek ini, mahasiswa juga mengalami kesulitan terutama dalam menentukan ungkapan. Ungkapan adalah adalah gabungan kata yang maknanya tidak sama dengan makna kata yang menjadi anggotanya. (makna kambing hitam tidak sama dengan makna kambing atau hitam). Ungkapan banyak digunakan dalam berbagai cerita atau percakapan tidak resmi. Oleh karena itu, mahasiswa diminta untuk membawa buku yang berkaitan dengan ungkapan dan memanfaatkan kamus ungkapan yang ada di perpustakaan sekolah. Selain itu, Pertanyaan yang diberikan tidak bersifat langsung tetapi dengan menggunakan acuan terlebih dahulu. Namun, terlepas dari hal-hal tersebut masih ada faktor yang mempengaruhi peningkatan skor siswa seperti motivasi dari siswa dan tingkat intelegensi siswa.

Berdasarkan hasil temuan lengkap diketahui bahwa peningkatan yang terjadi pada empat aspek tersebut skor kumulatif siswa siklus 1 memperoleh persentase skor sebesar $72 \%$ dan siklus 2 sebesar $80 \%$ sehingga memperoleh kenaikan sebesar $8 \%$.

Dengan adanya peningkatan skor rata-rata tiap siklus dan skor kumulatif membuktikan bahwa pembelajaran menyimak dongeng dengan menggunakan metode mind map melalui media animasi audiovisual dapat memotivasi mahasiswa dalam menyimak dan akhirnya berpengaruh terhadap penguasaan kemampuan menyimak khususnya menyimak dongeng. 


\section{KESIMPULAN}

Berdasarkan pelaksanaan penelitian tindakan Kelas tentang pembelajaran dengan metode pembelajaran mind map melalui media animasi audiovisual untuk meningkatkan kemampuan menyimak dongeng KD Menemukan hal-hal yang menarik dari dongeng yang diperdengarkan kelas A angkatan 2014 IKIP Budi Utomo Malang dapat disimulkan, penerapan metode pembelajaran mind map melalui media animasi audio visual dalam pembelajaran menyimak dongeng dengan kompetensi dasar menemukan hal-hal yang menarik dari dongeng yang diperdengarkan di kelas A angkatan 2014 IKIP Budi Utomo Malang dilakukan dengan cara, menyimak dongeng yang diberikan oleh dosen dari VCD, Membuat catatan dari dongeng yang disimak dengan memulai dari bagian tengah kertas kosong yang sisi panjangnya diletakkan mendatar karena memulai dari tengah memberi kebebasan kepada otak untuk menyebar ke segala arah dan untuk mengungkapkan dirinya dengan lebih bebas dan alami, memberi gambar atau foto untuk ide utama karena sebuah gambar bermakna seribu kata dan membantu kita menggunakan imajinasi. Sebuah gambar sentral akan lebih menarik, membuat kita tetap terfokus, membantu kita berkonsentrasi, dan mengaktifkan otak kita.

Metode Pembelajaran mind map melalui media animasi audiovisual dapat meningkatkan kemampuan menyimak dongeng siswa kelas A angkatan 2014 IKIP Budi Utomo Malang. Berdasarkan hasil evaluasi siklus 1 dan siklus 2 dapat dibuktikan perolehan skor kumulatif terjadi peningkatan dan masing-masing aspek juga terjadi peningkatan kecuali pada aspek kemenarikan relevansi dongeng. Dari hasil observasi juga terjadi peningkatan, secara umum kondisi pembelajaran cukup kondusif. Situasi kelas dapat dikendalikan, mahasiswa merasa senang dengan metode mind map dan VCD dongeng yang digunakan sebagai media untuk menyimak dongeng. Minat mahasiswa dalam mengikuti kegiatan menyimak dongeng cukup besar.

\section{SARAN}

Hasil penelitian menunjukkan bahwa penerapan metode pembelajaran mind map melalui media animasi audiovisual dapat meningkatkan kemampuan menyimak dongeng mahasiswa kelas A angkatan 2014 IKIP Budi Utomo Malang. Oleh karena itu, peneliti memberikan saran kepada dosen, guru, kepala sekolah, dan peneliti lain. Saran tersebut dapat diuraikan sebagai berikut: Hendaknya dosen dapat: (a) Menerapkan metode pembelajaran mind map melalui media animasi audiovisual sebagai variasi metode pembelajaran agar mahasiswa tidak merasa jenuh dalam mengikuti pembelajaran, (b) Memilih metode pembelajaran yang sesuai dan efektif dalam penyampaian mata kuliah menyimak karya sastra, sehingga dapat meningkatkan kualitas mata kuliah menyimak karya sastra, (c) Agar pengetahuan mahasiswa dapat berkembang, maka sebaiknya mahasiswa diberikan tindak lanjut untuk membuat catatan dengan menggunakan metode mind map untuk pembelajaran berikutnya. Keterbatasan penelitian ini adalah penerapan metode pembelajaran mind map pada penelitian ini dikhususkan pada penilaian aspek kognitif dan psikomotor saja. Sehingga disarankan bagi peneliti lanjut, coba meneliti penerapan metode pembelajaran mind map dalam upaya untuk meningkatkan aspek afektif siswa.

\section{DAFTAR RUJUKAN}

Arikunto, S., dkk. 2009. Penelitian Tindakan Kelas. Jakarta: Bumi Angkasa.

Buzan, T. 2010. Buku Pintar Mind Map. Jakarta: Gramedia. 
74\| Luly Zahrotul, Peningkatan Kemampuan Menyimak Dongeng..... 